\title{
Corrosion in marine and offshore steel structures: Classification and overview
}

\author{
Nour Eldeen M. A. Abo Nassar \\ Civil Engineering Department, Near East University, Nicosia, Via Mersin 10, Turkey
}

\section{A R T I C LE INFO}

\section{ARTICLE HISTORY}

Received: 20 February 2021

Revised: 11 April 2021

Accepted: 04 May 2021

Published: 30 May 2021

\section{KEYWORDS:}

Corrosion, steel corrosion, cathodic protection, coatings, corrosion allowance

\section{A B S T R A C T}

Marine services and industry have emerged as one of the most significant pillars of global economic growth. Corrosion of materials, on the other hand, is still the most important issue for marine structures and equipment. Corrosion is a major contributor to the degradation of marine and offshore structures. It has an effect on the life of process equipment, and might lead to structural failure, leakage, product degradation, contamination, and even death. It is important to investigate the mechanisms of material corrosion in the marine environment, as well as corrosion prevention methods, in order to make effective use of marine resources. Various mitigation techniques, like the utilization of coatings, cathodic protection, and corrosion allowance are utilized to protect offshore structures against corrosion. In general, the marine environment has a significant impact on the protection of offshore structures. Therefore, the goal of this article is to give an overview about corrosion of marine structures, how it happens and some of the current prevention techniques.

\section{INTRODUCTION}

Offshore structures are one of the world's most important and tallest structures that must function safely in a variety of harsh environments, and have a direct effect on a country's economy and industrial development (Nouban et al., 2016). The marine environment has a significant impact on the protection of offshore structures, which potentially causing harm to the structures through the degradation process (Zhang, 2015). When evaluating the performance of an existing offshore system, the corrosion process has received a lot of attention (Melchers, 2003). This is especially critical because most offshore structures are subjected to a harsh environment that can hasten structural degradation.

One of the most important issues that offshore structures face is corrosion. Corrosion is a major factor affecting the longevity, protection, and long-term viability of buildings and structures (James et al., 2019). Corrosion-induced failure can result in severe safety incidents as well as financial losses. The characteristics of materials and structures in the marine environments deteriorate over time as a result of various parameters eroding at the same time (Toloei et al., 2013). These parameters such as; dissolved oxygen, temperature, salinity, $\mathrm{pH}$, seawater speed, and other variables. Corrosion progresses more quickly in an offensive setting (Cai et al., 2020).

It is important to investigate the mechanisms of material corrosion in the marine environment, as well as corrosion prevention methods, in order to make effective use of marine resources (Wang, 2006). There are a number of ways to monitor corrosion of offshore properties. Corrosion protection techniques like cathodic protection and coatings are very common (Paul, 2018; Tezdogan \& Demirel, 2014).

The reminder of the article is structured as: in section 2 the methodology of the study is presented. Information about corrosion problem in marine environments is given in section 3. Corrosion rate determination is illustrated in section 4. Corrosion protection systems are given in section 5. Lastly, the conclusion is presented in section 6 .

\section{METHODOLOGY}

This paper is a review study for the topic of "Corrosion of steel structures in the marine and offshore industries". As 
two of the most common and largest online sources for high quality results related to the topic, Scopus and Google Scholar databases were used to collect data. Keywords such as "corrosion," "cathodic protection," and "coatings" were used.

\section{CORROSION AND CORROSION PROBLEM IN MARINE ENVIRONMENTS}

\subsection{Corrosion mechanism}

According to Tezdogan \& Demirel (2014), "corrosion is a damaging assault of a substance through interaction with its surroundings". Rust is the most common corrosion output, that is produced when steel and iron enter the corrosion process. A corrosion cell is shown in Figure 1 as a simple schematic.

Since corrosion damage is expensive to fix, approaches that can avoid corrosion are given a lot of importance.

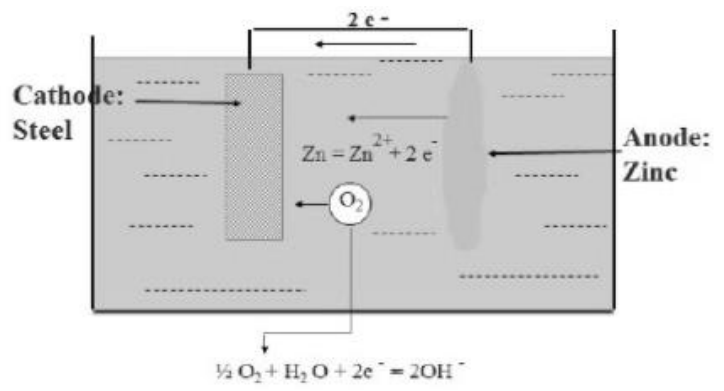

Fig. 1. A corrosion cell (Tezdogan \& Demirel, 2014)

\subsection{The corrosion problem in the marine environments}

According to (Kirchgeorg et al., 2018) the harsh marine environment poses a significant challenge to the constructions and longevity of offshore frameworks, that are mostly constructed of steel and are designed to more than 25 years. The chemical characteristics of the immersing medium, (such as seawater and brackish water), have a significant impact on metal corrosion. In comparison to drinking water, seawater is extremely corrosive, as corrosion increases with salinity, but other factors like oxygen concentration, $\mathrm{pH}$ (for seawater ranging between 7.8 and 8.3), and temperature also influence corrosion process.

Prabhakar and Goswami (2019), stated that in the context of Offshore structures, corrosion is electrochemical processes. In this electrochemical process, the electrolyte is the seawater, and due to various potentials between different sections of the steel structures, the metal ions travel from the structure's surface and diffuse into the electrolyte solution.
Table 1. Corrosion zones in offshore materials and structures

\begin{tabular}{|l|l|}
\hline Zone & Description \\
\hline \multirow{5}{*}{ Atmospheric } & $\begin{array}{l}\text { The location of atmospheric zone is above sea } \\
\text { level, in which corrosion intensity is linked to } \\
\text { the period of moisture, through which } \\
\text { electrochemical process occur. In this zone, a } \\
\text { direct relation between the amount of salt in } \\
\text { the atmosphere and the rate of corrosion exist. } \\
\text { In addition, materials are often subjected to } \\
\text { solar radiation, that degrades the efficiency of } \\
\text { the organic coating. }\end{array}$ \\
\hline Splash zone & $\begin{array}{l}\text { This zone has the highest rate of metal } \\
\text { corrosion because of the aerated atmosphere, } \\
\text { which allows for easy access to dissolved } \\
\text { oxygen for electrochemical reaction. In } \\
\text { addition, because of the tides and the wind, } \\
\text { this part of the structure is sometimes damp. }\end{array}$ \\
\hline Tidal zone & $\begin{array}{l}\text { If the tide changes, the objects are alternately } \\
\text { immersed and subjected to the splash zone. } \\
\text { When materials are submerged, they are } \\
\text { exposed to well-aerated seawater, which } \\
\text { encourages biofouling attachment and } \\
\text { development. The rate of corrosion is affected } \\
\text { by the tidal flow, with greater rates of } \\
\text { corrosion as the tidal flow increases. }\end{array}$ \\
\hline zone & $\begin{array}{l}\text { The section of the structure that is constantly } \\
\text { submerged in the sea. The availability of } \\
\text { oxygen to transport to the cathodic sites of the } \\
\text { substances surfaces determines the rate of } \\
\text { corrosion in this zone. Since oxygen } \\
\text { concentration differs with depth and decreases } \\
\text { as distance from the surface increases, the } \\
\text { corrosion rate is slower at greater depth. }\end{array}$ \\
\hline The oxygen concentration in the buried \\
structure is low, and hydrogen sulfide might \\
be present.
\end{tabular}

Corrosion outputs are formed when metal ions interact with oxide and hydroxide ions. Since dissolved oxygen levels are higher near the water's surface, the presence of dissolved oxygen becomes a major concern. Because of this proximity, the dissolved oxygen imposes a higher corrosive over potential in the neighbourhood of this area in comparison to the metal below the surface. As a consequence of this, pits may form on the platform's metal surface. Corrosion in the pits and the crevices (like the structure's joints or welding defects), appears as frequent corrosion on the platform's steel surface. Increased stresses due to pits, crevices, and other structural irregularities (due to electrochemical reactions) cause cracks and breaks in the structure over time. The corrosion rate depends on the metal's microstructure.

According to López-Ortega et al. (2019), as shown in Table one below, offshore materials and frameworks are subjected to 5 distinct corrosion areas, each with various rates of material corrosion. 


\section{CORROSION RATE DETERMINATION}

According to Ting et al. (2011), the corrosion rates of structural steel in the harsh environments of coastal areas, harbours and oceans has an impact on the economic benefit of marine structures, as steel loss and pitting can have major effects on structural protection and efficiency. With a growing focus on keeping existing structures in operation for longer time spans and thereby deferring replacement cost, there is a growing interest in predicting corrosion rates at a given location for a given duration of exposure once the protection (coatings or cathodic protections) is lost.

Paul (2012), stated that because of the wide range of parameters that control the corrosion rate, predicting the corrosion rates of steel structures in the universal marine environments is a difficult task. The key factors that affect the rate could include; salinity, sulfate, dissolved oxygen, $\mathrm{pH}$ as well as temperatures. Although the individual impacts of these factors on corrosion are well understood, the combined influence of these factors together are complicated and unknown.

Table 2. Examples on corrosion rates from different locations

\begin{tabular}{|l|c|c|}
\hline \multicolumn{1}{|c|}{ Location } & $\begin{array}{c}\text { Exposure } \\
\text { time (Year) }\end{array}$ & $\begin{array}{c}\text { Rate of } \\
\text { corrosion } \\
\text { (mm/y) }\end{array}$ \\
\hline Gulf of Mexico & - & 1.4 \\
\hline Alaska & - & 0.90 \\
\hline $\begin{array}{l}\text { North Sea - United } \\
\text { Kingdom }\end{array}$ & 7.2 & 0.154 \\
\hline Taylor Beach - Australia & 2.2 & 0.136 \\
\hline Sakata Harbour - Japan & 0.5 & 0.089 \\
\hline $\begin{array}{l}\text { Coffs Harbour - } \\
\text { Australia }\end{array}$ & 2 & 0.150 \\
\hline Campeche - Mexico & - & 0.280 \\
\hline $\begin{array}{c}\text { Harbour Island - United } \\
\text { States }\end{array}$ & 5 & 0.250 \\
\hline Port Adelaide - Australia & 52 & 0.031 \\
\hline \begin{tabular}{l} 
Yokohama Port - Japan \\
\hline
\end{tabular} & 11 & 0.182 \\
\hline
\end{tabular}

Valdez et al. (2016) stated that, throughout the erosion processes, marine frameworks lose wall thickness at a rate that differs with depths. Steel corrosion rates in seawater are normally between $0.1-0.3 \mathrm{~mm} / \mathrm{year}$, but in seawater polluted with corrosive effluents, can reach 2-4 mm/year.

According to the work done by (Khodabux et al., 2020), some examples about corrosion rates from different locations are shown in Table 2.

\section{CORROSION PROTECTION SYSTEMS}

There are many ways to keep a substance from corroding. Corrosion protection techniques like cathodic protection, corrosion allowance and coatings are very common.

\subsection{Cathodic protection systems (CPS)}

CPS are among the widely utilized methods for all types of steel structures in marine and harbour settings, such as ships and infrastructure (Kirchgeorg et al., 2018). Shehadeh and Hassan (2013) stated that, CPS is commonly utilized to maintain steel marine structures from corrosion caused by seawater (such as ships, pipelines, offshore structures, and others). Seawater is considered a hostile environment on marine ships as well as offshore steel structures due to its high electric conductivity and high amount of oxygen. Therefore, the aim of this technique is to transform the metallic structure into a cathode of an electrochemical cell, to conduct electrons for cathodic reactions.

According to Shehadeh and Hassan (2013), CP can be accomplished in two ways; the first one is the impressed current cathodic protection systems while the second is the sacrificial anodes cathodic protection systems (see Table 3 ).

Table 3. Cathodic protection systems types

\begin{tabular}{|l|l|}
\hline \multicolumn{1}{|c|}{ ICCP system } & \multicolumn{1}{|c|}{ SACP system } \\
\hline $\begin{array}{l}\text { In this system, an external DC } \\
\text { power source is used to } \\
\text { generate electrons. The system }\end{array}$ & $\begin{array}{l}\text { In SACP system, reactive } \\
\text { metals are utilized like } \\
\text { anodes which are electrically } \\
\text { is made up of; rectifier, } \\
\text { attached to the metals to be } \\
\text { arotected. The difference in } \\
\text { and control unit. The rectifier } \\
\text { provides the requisite positive } \\
\text { current, that is then connected } \\
\text { to the structure to be secured } \\
\text { by the anodes. During this } \\
\text { the anodes and the metals, as } \\
\text { operation, the reference } \\
\text { electrodes keep track of the } \\
\text { protections level while the } \\
\text { positions in the galvanic } \\
\text { series, generates a positive } \\
\text { current that flows in the } \\
\text { electrolyte, from the anodes } \\
\text { to the metal. As a result, the } \\
\text { metal's entire surface } \\
\text { current unit adjusts the output } \\
\begin{array}{l}\text { Ultimately, the metal structure } \\
\text { become passively charged, } \\
\text { becomes more negatively } \\
\text { that eventually causes the } \\
\text { potential to fall below a a } \\
\text { predetermined level. }\end{array}\end{array} \begin{array}{l}\text { cathode. Aluminium, zinc, } \\
\text { and magnesium are the most } \\
\text { common metals used as } \\
\text { sacrificial anodes (Safuadi et } \\
\text { al., 2011). }\end{array}$ \\
\hline
\end{tabular}

\subsection{Corrosion allowance $(\mathrm{CA})$}

According to Kirchgeorg et al. (2018), the meaning of corrosion allowance is the use of thicker steel as necessary for the constructions. If conventional protection systems fail, or if coating damage occurs, this can be used as a backup solution. In addition, a CA is required to cover the 
time durations up to the ICCP installation and steel polarization. This can extend the structure's life in the event of technical issues with impressed current cathodic protection system or galvanic anodes (such as passivation). The thickness is determined based on the estimated erosion rate of the steel in the marine environments. Corrosion allowances of 0.2 to 1.20 centimetre are recommended. The steel is mostly made of iron, and also includes traces ranging from 0.01 to 1.65 percent of $\mathrm{C}, \mathrm{Si}, \mathrm{Mn}, \mathrm{S}, \mathrm{P}, \mathrm{Al}, \mathrm{Ni}, \mathrm{Mo}, \mathrm{Cr}$, $\mathrm{V}, \mathrm{Co}$, and $\mathrm{Cu}$.

\subsection{Coating systems (CS)}

CS is a simple way to prevent corrosion. During this method, a barrier is built between the steel and the sea water, thus the surface is isolated. According to Price and Figueira (2017), While CS may combine several layers of various kinds of coatings, consistency between the layers must be ensured. Non-metallic coatings, metallic coatings, or a mixture of these 2 kinds of coatings are applied to the surface of the steel during the coating process. Metallic coatings generally consist of non-ferrous metals, usually zinc, aluminium and its alloys. Non-Ferrous metals have higher impedance to corrosion compared to carbon steels. These metallic coatings protect the steel frameworks from erosion by galvanizing and barrier. Furthermore, metallic coatings virtually conserve the steel in damaged places or where small pores in the coating exist.

According to Tezdogan and Demirel (2014), paint protects against corrosion in 3 ways: by creating a barrier effect, inhibiting corrosion, and supplying a galvanic effect. The barrier effect, as the name implies, creates a barrier between the materials and the environment.

Inhibiting dyes, like zinc phosfate, are utilized in inhibitory paints. Such pigments utilized only in primers. It is important to note that these paints are not appropriate for utilization below the water.

Paints using the galvanic effect include zinc (pure) pigments and are utilized just like a primer. Galvanic effect is based on the fact that zinc makes a metallic contact with steel, allowing it to act like anodes. Even if the coating is cracked or peeled off, the steel continues to be conserved by zinc cathode pigment.

\subsection{Combined utilization of cathodic protection and coatings}

According to Tezdogan and Demirel (2014), over time, the painted surface is subject to deteriorate. Unless the system is repaired, the system's characteristics sometimes fall below the limiting standard after a certain amount of time in operation. This eventually results in a high renovation cost. Cathodic protection, on the other hand, will increase the system's protection.

Compatibility between the coating system and the $\mathrm{CP}$ is an important consideration when designing cathodic protection; if not, then proper protection cannot be guaranteed. Standard laboratory tests, like ASTM G8, are commonly used to assess the coatings' compatibility.

\section{CONCLUSION}

In conclusion, a comprehensive review of the corrosion problems in marine and offshore structures including the causes, mechanisms, impacts, monitoring and prevention are studied. Corrosion of marine offshore structures is clearly a serious issue and must be taken into account when designing such structures that are subject to aggressive environments.

\section{REFERENCES}

[1] Cai, Y., Xu, Y., Zhao, Y., Zhou, K., \& Ma, X. (2020). A spatial-temporal approach for corrosion prediction in time-varying marine environment. Journal of Loss Prevention in the Process Industries, 66, 104161. https://doi.org/10.1016/j.jlp.2020.104161

[2] James, A., Bazarchi, E., Chiniforush, A. A., Aghdam, P. P., Hosseini, M. R., Akbarnezhad, A., \& Ghodoosi, F. (2019). Rebar corrosion detection, protection, and rehabilitation of reinforced concrete structures in coastal environments: A review. Construction and Building Materials, 224, 1026-1039.

https://doi.org/10.1016/j.conbuildmat.2019.07.250

[3] Khodabux, W., Causon, P., \& Brennan, F. (2020). Profiling corrosion rates for offshore wind turbines with depth in the North Sea. Energies, 13(10), 2518. https://doi.org/10.3390/en13102518

[4] Kirchgeorg, T., Weinberg, I., Hörnig, M., Baier, R., Schmid, M. J., \& Brockmeyer, B. (2018). Emissions from corrosion protection systems of offshore wind farms: Evaluation of the potential impact on the marine environment. Marine pollution bulletin, 136, 257-268. https://doi.org/10.1016/j.marpolbul.2018.08.058

[5] López-Ortega, A., Bayón, R., \& Arana, J. L. (2019). Evaluation of protective coatings for high-corrosivity category atmospheres in offshore applications. Materials, 12(8), 1-21. https://doi.org/10.3390/ma12081325

[6] Melchers, R. E. (2003). Modeling of marine immersion corrosion for mild and low-alloy steels-Part 1: Phenomenological model. Corrosion, 59(4), 319-334. https://doi.org/10.5006/1.3277564

[7] Nouban, F., French, R., \& Sadeghi, K. (2016). General guidance for planning, design and construction of offshore platforms. Academic Research International, 7(5), 37-44.

[8] Paul, S. (2012). Modeling to study the effect of environmental parameters on corrosion of mild steel in 
seawater using neural network. International Scholarly

https://doi.org/10.1260/1369-4332.18.8.1159

Research Notices, 2012, 1-6.

https://doi.org/10.5402/2012/487351

[9] Paul, S. (2018). Cathodic Protection of Offshore Structures by Extreme Damage Tolerant Sacrificial Coatings. In NACE International Corrosion Conference Proceedings, 1-12.

[10] Prabhakar, S., \& Goswami, G. (2019). Design, Management and Key Success Factors of an Offshore Cathodic Protection System for Corrosion Control. International Journal of Engineering and Management Research, 9(2), 171-177. https://www.doi.org/10.31033/ijemr.9.2.23

[11] Price, S. J., \& Figueira, R. B. (2017). Corrosion protection systems and fatigue corrosion in offshore wind structures: current status and future perspectives. Coatings, 7(2), 25. https://doi.org/10.3390/coatings7020025

[12] Safuadi, M., Ridha, M., Huzni, S., Fonna, S., Ariffin, A. K., \& Daud, A. R. (2011). Optimization of Cathodic Protection System Design for Pipe-Lines Structure with Ribbon Sacrificial Anode Using BEM and GA. In Key Engineering Materials, (462), 1267-1272. https://doi.org/10.4028/www.scientific.net/KEM.462463.1267

[13] Shehadeh, M., \& Hassan, I. (2013). Study of sacrificial cathodic protection on marine structures in sea and fresh water in relation to flow conditions. Ships and Offshore Structures, 8(1), 102-110. https://doi.org/10.1080/17445302.2011.590694

[14] Tezdogan, T., \& Demirel, Y. K. (2014). An overview of marine corrosion protection with a focus on cathodic protection and coatings. Brodogradnja: Teorija i praksa brodogradnje i pomorske tehnike, 65(2), 49-59.

[15] Ting, O. S., Potty, N. S., \& Liew, M. S. (2011). Prediction of corrosion rates in marine and offshore structures. In 2011 National postgraduate conference, 1-6. https://doi.org/10.1109/NatPC.2011.6136376

[16] Toloei, A., Atashin, S., \& Pakshir, M. (2013). Corrosion rate of carbon steel under synergistic effect of seawater parameters including $\mathrm{pH}$, temperature, and salinity in turbulent condition. Corrosion Reviews, 31(3-6), 135-144. https://doi.org/10.1515/corrrev-2013-0032

[17] Valdez, B., Ramirez, J., Eliezer, A., Schorr, M., Ramos, R., \& Salinas, R. (2016). Corrosion assessment of infrastructure assets in coastal seas. Journal of Marine Engineering \& Technology, 15(3), 124-134. https://doi.org/10.1080/20464177.2016.1247635

[18] Wang, G. P. (2006). Marine coatings and coating technology. Chemical Industry Press, Beijing.

[19] Zhang, Y. (2015). Comparing the robustness of offshore structures with marine deteriorations-a fuzzy approach. Advances in Structural Engineering, 18(8), 1159-1171. 